
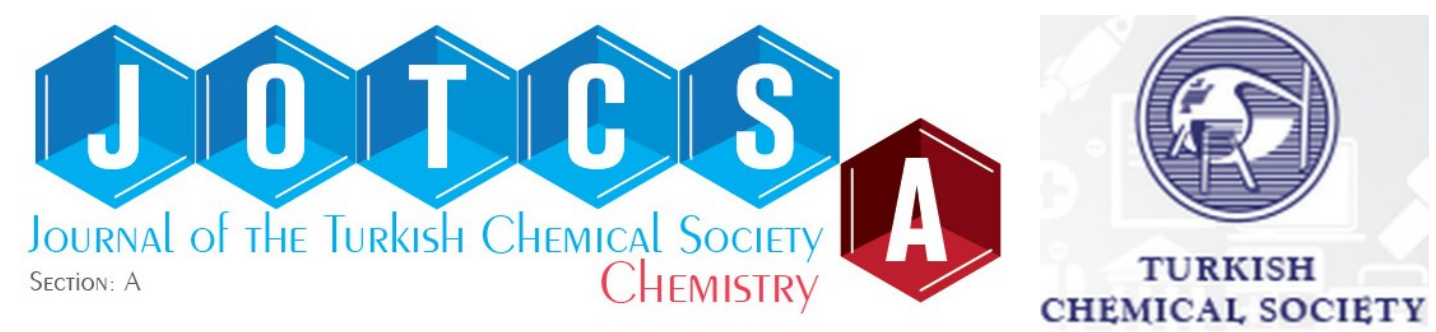

\title{
An improved isolation of trimyristin from Myristica fragrans as a renewable feedstock with the assistance of novel cationic gemini surfactant
}

\author{
Ayhan YILDIRIM $\triangle D$, Serkan ÖZTÜRK $\triangle D$, Haluk TÜRKDEMIR $\triangle(D$, Atakan KOLALI $\triangle$ \\ , Beyza Gökçem ATALAY $\triangle$, Hatice KOCATAŞ $\triangle$
}

Bursa Uludağ University, Faculty of Arts and Sciences, Department of Chemistry, 16059, Bursa, Turkey.

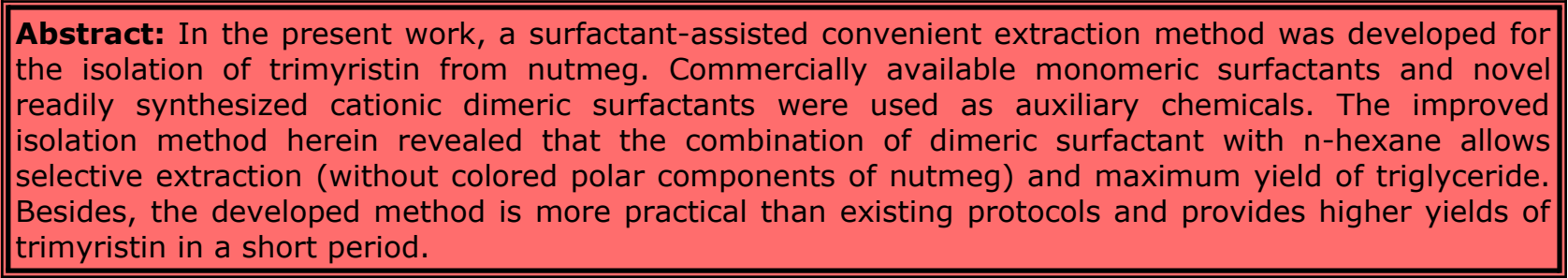

Keywords: Nutmeg, triglycerides, surfactant-assisted extraction, renewable materials.

Submitted: August 16, 2019. Accepted: May 18, 2020.

Cite this: YILDIRIM A, ÖZTÜRK S, TÜRKDEMİR H, KOLALI A, ATALAY BG, KOCATAŞ H. An improved isolation of trimyristin from Myristica fragrans as a renewable feedstock with the assistance of novel cationic gemini surfactant. JOTCSA. 2020;7(2):545-60.

DOI: https://doi.org/10.18596/jotcsa.605805.

*Corresponding author. E-mail: yildirim@uludag.edu.tr.

\section{INTRODUCTION}

The necessary chemical raw materials required by the chemical, pharmaceutical, textile, and food industries have been provided for a long time from crude oil. However, the depletion of oil reserves, the cost of production and derivatization processes of different petrochemicals and excessive energy requirements have led both the academic and the industrial community to the search for new sources of raw materials. It is becoming increasingly popular to find more environmentally friendly, biodegradable, and renewable raw material resources. Among these feedstock sources, animal and vegetable-originated fats and oils are particularly remarkable $(1,2)$. Vegetable oils are biomass that has the potential to replace many chemicals in oil refineries, and the main component of this biomass is triglycerides, also known as triacylglycerol (3). Triglycerides are receiving increased interest owing to their potential as a starting material for the production of biofuel and as a source for valuable renewable raw chemicals (4-6). As a result of pyrolysis or thermal and catalytic cracking processes performed with triglycerides, bio-based versatile chemicals can be prepared suitable for different industrial fields (79).

Lipids are often found in tissues with carbohydrates and proteins, which makes their isolation difficult. Triglycerides and many other natural compounds of the lipid class are generally isolated from plant sources like canola and Jatropha curcas by extraction techniques, and supercritical carbon dioxide is the widely used solvent along with other supercritical fluids (1012). The triglyceride ratios and compositions of 
lipid extracts obtained from several vegetable sources show variability. For instance, Myristica fragrans seeds (nutmeg) are rich in myristicin as one of the necessary components of its essential oil and trimyristin as a major triglyceride component (13-15). As known, trimyristin is a neutral lipid component, and non-polar solvents such as ether, n-hexane, and chloroform are suitable for its extraction. Trimyristin is a yellowish-white solid at room temperature, formed by esterification of glycerol with myristic acid as a saturated fatty acid. It is a raw material for the soap and oleochemical industries and widely used in the cosmetic industry (16). In the cosmetic industry, trimyristin can be classified as the following: emollient, refatting, skin conditioning, solvent, and viscosity controlling agent. It is used in makeup products, deodorants, creams and lotions, suntan and sunscreen products, hair conditioners, skincare, and skin cleansing products. Therefore, it is crucial to develop efficient extraction procedures to obtain this particular triglyceride with high yields. Unfortunately, it can be grown on an industrial scale only in regions with a tropical climate.

Beal reported a convenient ether-based isolation method with Soxhlet extractor, which requires a long time (24 to 72 hrs.), and the yield of the purified trimyristin was approximately $53 \%$ based on the mass of crude nutmeg extract (17). According to a procedure recommended by Ikan, extraction was carried out with chloroform as a solvent, and after the purification stage, trimyristin was obtained with a yield of $20 \%$ based on the mass of crushed nutmeg materials (18). Lugemwa used water-organic solvent mixtures for the isolation of trimyristin from nutmeg and obtained the desired triglyceride with a yield of only $8 \%$ at the end of 1 hour of extraction (19). On the other hand, some isolation methods designed as general chemistry experiments have also been developed but with a lower yield of trimyristin based on the mass of crude nutmeg extract $(20,21)$.

As is known, surfactants are both hydrophilic and lipophilic compounds which make them unique tools in isolation of various natural compounds via extraction processes (22-30). At the extraction stage, the combination of solvent with surfactant molecules facilitates the penetration of solvent molecules throughout seed cell walls. To the best of our knowledge, there has been no work investigating the surfactant-assisted isolation of trimyristin from nutmeg. In this work, we report the synthesis of a novel cationic gemini surfactant and its evaluation in an efficient extraction process of trimyristin from nutmeg.

\section{EXPERIMENTAL SECTION}

\section{Reagents and chemicals}

All reagents and solvents were purchased from either Merck or Sigma-Aldrich (St. Louis, MO) and used without further purification. Thin-layer chromatography (TLC) was performed using silica gel plates ( $60 \mathrm{~F}_{254}$, Merck, Darmstadt, Germany).

\section{Analytical techniques}

Melting points were recorded by $\mathrm{BÜCHI}$ melting point B-540 apparatus (BÜCHI Labortechnik AG in Flawil, Switzerland). The Fourier Transformed Infrared (FTIR) spectra were measured using a PerkinElmer Spectrum 100 spectrometer. The Nuclear Magnetic Resonance (NMR) spectra were measured using Bruker Avance NEO $600 \mathrm{MHz}$ NMR spectrometer (Santa Clara, CA, USA). Chemical shifts $(\delta)$ are reported in $\mathrm{ppm}$, and $J$ values in Hertz. A Hitachi $3100 \mathrm{H}$ dual-beam spectrophotometer (Tokyo, Japan) was used for the spectrophotometric analyses. Conductivity measurements were performed using a Thermo Scientific ORION 3 STAR digital conductometer (Madison, WI, USA). The elemental analyses were performed using a LECO CHNS-932 elemental analyzer (Saint Joseph, MI, USA).

\section{Preparation of the surfactant}

$\mathrm{N}^{1}, \mathrm{~N}^{1}, \mathrm{~N}^{6}, \mathrm{~N}^{6}$-tetramethyl- $\mathrm{N}^{1}, \mathrm{~N}^{6}$-bis(4-((10-(5(octylthio)-1,3,4-oxadiazol-2-

yl)decyl)oxy)benzyl)hexane-1,6-diaminium chloride

$N, N, N^{\prime}, N^{\prime}$-Tetramethyl-1,6-hexanediamine $(0.15 \mathrm{~g}$, $0.87 \mathrm{mmol})$ and two equivalents of 2-(10-(4(chloromethyl)phenoxy)decyl)-5-(octylthio)-1,3,4oxadiazole (31) $(0.85,1.72 \mathrm{mmol})$ are heated in $\mathrm{MeCN}$ at $80{ }^{\circ} \mathrm{C}$ for $24 \mathrm{~h}$. After completion of the reaction, the mixture was cooled, and the excess of solvent was removed under reduced pressure. The residue is washed successfully with n-hexane. A white waxy product is obtained quantitatively in a sufficient purity.

Waxy solid (mp: $35-36{ }^{\circ} \mathrm{C}$ ); FTIR (ATR): $\mathrm{V}_{\max }$ 3351, 2919, 2852, 1667, 1612, 1586, 1514, 1484, $1474,1433,1367,1306,1252,1183,1146,1043$, 1018, 983, 958, 928, 865, 825, 795, 742, 718, $682,617,555,522 \mathrm{~cm}^{-1} ;{ }^{1} \mathrm{H}$ NMR (600 MHz, $\left.\mathrm{CDCl}_{3}\right) \delta$ 7.50-7.47 (m, 4H, Ar), 6.87-6.85 (m, 4H, $\mathrm{Ar}), 4.74\left(s, 4 \mathrm{H}, 2 \times \mathrm{ArCH}_{2} \mathrm{~N}^{+}\right), 3.90(t, J=6.4 \mathrm{~Hz}$, $\left.4 \mathrm{H}, 2 \times \mathrm{ArOC}_{2}-\right), 3.60(t, J=7.4 \mathrm{~Hz}, 4 \mathrm{H}, 2 \times$ $\left.\left(\mathrm{CH}_{3}\right)_{3} \mathrm{~N}^{+} \mathrm{CH}_{2} \mathrm{CH}_{2}^{-}\right), 3.18(t, J=7.4 \mathrm{~Hz}, 4 \mathrm{H}, 2 \mathrm{x}$ HetSC $\left.\mathrm{H}_{2} \mathrm{CH}_{2}-\right), 3.15\left(\mathrm{~s}, 12 \mathrm{H}, 2 \times-\mathrm{N}^{+}\left(\mathrm{CH}_{3}\right)_{2}\right), 2.77$ $\left(t, J=7.4 \mathrm{~Hz}, 4 \mathrm{H}, 2 \times \mathrm{HetC}_{2} \mathrm{CH}_{2}^{-}\right), 2.04-2.01(m$, $\left.4 \mathrm{H}, 2 \times \mathrm{HetSCH}_{2} \mathrm{CH}_{2} \mathrm{CH}_{2}-\right), 1.77-1.70(m, 12 \mathrm{H}, 6 \times$ $\left.\mathrm{CH}_{2}\right), 1.43-1.32\left(m, 16 \mathrm{H}, 8 \times \mathrm{CH}_{2}\right), 1.28-1.23(\mathrm{~m}$, $\left.32 \mathrm{H}, 16 \times 1.36 \mathrm{CH}_{2}\right), 0.84(t, J=7.1 \mathrm{~Hz}, 6 \mathrm{H}, 2 \times-$ $\left.\mathrm{CH}_{2} \mathrm{C}_{3}\right) ;{ }^{13} \mathrm{C} \mathrm{NMR}\left(150 \mathrm{MHz}, \mathrm{CDCl}_{3}\right) \delta$ 167.91, 
$164.24,160.77,134.57,119.12,114.90,68.13$ $67.27,64.17,49.24,42.96,32.47,31.69,29.42$, $29.31,29.29,29.20,29.11,29.04,29.03,28.92$, $28.91,28.53,26.36,25.96,25.35,24.96,22.56$, 21.70 , 14.03; Anal calc for $\mathrm{C}_{64} \mathrm{H}_{110} \mathrm{Cl}_{2} \mathrm{~N}_{6} \mathrm{O}_{4} \mathrm{~S}_{2}$ (1162.64): C 66.12, H 9.54, N 7.23, S 5.52. Found: C 66.15, H 9.49, N 7.27, S 5.50.

\section{Conductivity measurements}

Conductivity measurements were performed using a Thermo Scientific ORION 3 STAR digital conductometer apparatus (Madison, WI, USA). To measure the specific conductivity at each surfactant, we followed the step-by-step dilutionextraction method. The critical micellar concentration $(\mathrm{cmc})$ value was estimated from the breakpoint on the curve of conductivity versus surfactant concentration.

\section{Surface tension measurement at cmc}

The capillary rise method is used to measure the surface tension of aqueous solution of the synthesized cationic surfactant at $\mathrm{cmc}(32,33)$. The corresponding value was measured at $20^{\circ} \mathrm{C}$.

\section{Emulsion stability}

Emulsion stability was determined by mixing the aqueous solution of the surfactants with the mineral oil in a graduated cylinder with a plastic stopper. An aqueous solution of the surfactant at the $\mathrm{cmc}(10 \mathrm{~mL})$ was poured into a $100 \mathrm{~mL}$ cylinder containing $10 \mathrm{~mL}$ mineral oil. The glass cylinder was closed with a stopper. The mixture was shaken by turning the glass cylinder vigorously up and down for $30 \mathrm{~s}$ at a constant speed, and then the time for the separation of 9 $\mathrm{mL}$ of clean surfactant solution was noted (34).

\section{Ultraviolet (UV) spectrophotometric analysis}

A Hitachi $3100 \mathrm{H}$ dual-beam spectrophotometer was used for spectrophotometric analysis. The spectra of the compounds were viewed at a wavelength range of 1100-190 nm. Since no peak was observed in the near IR and Visible (VIS) regions, comparative spectra were taken at a range of 500-190 nm. For the cationic surfactant, spectra of solutions with various concentrations $\left(1.0 \times 10^{-6}-2.5 \times 10^{-5}\right) \mathrm{M}$ and separately $1.0 \times 10^{-4} \mathrm{M}$ on the curve were taken.

\section{General extraction and purification procedure for trimyristin}

The Myristica fragrans seeds were ground using a porcelain mortar and pestle at ambient temperature just before extraction to isolate triglycerides more efficiently. From this undried crushed sample, exactly 1 gram was weighed, placed in a $50 \mathrm{~mL}$ single-necked flask, and was extracted at $50{ }^{\circ} \mathrm{C}$ for $20 \mathrm{~min}$ with $20 \mathrm{~mL}$ of the solvent indicated in the present work. In the case of surfactant-assisted extractions, $5 \mathrm{mg}$ of the related surfactant was also added into the flask. After that, the obtained mixture was filtered, and the filtrate was evaporated in a vacuum. The residue was weighed and recrystallized from acetone to afford pure trimyristin as a white solid with $\mathrm{mp}$ : $55-56{ }^{\circ} \mathrm{C}$. However, the triglyceride is sufficiently pure and can be used for many purposes without further purification.

\section{RESULTS AND DISCUSSION}

\section{Synthesis and physicochemical characterization of the surfactant}

1,3,4-oxadiazole based long-chain benzyl chloride derivative (31) was treated with $N, N, N^{\prime}, N^{\prime}-$ tetramethyl-1,6-hexanediamine, as shown in Scheme 1, to prepare the cationic gemini type surfactant. The structure of the novel surfactant was confirmed by FTIR, ${ }^{1} \mathrm{H} N \mathrm{NMR}$, and ${ }^{13} \mathrm{C}$ NMR spectroscopic methods (Appendix A. Supplementary material, S2). The evaluation of ${ }^{1} \mathrm{H}$ NMR spectrum showed that $\left(\mathrm{ArC}_{2} \mathrm{~N}^{+}\right)$benzyl protons appear as a singlet at 4.74 ; methylene protons of $\left(\mathrm{ArOC}_{2} 2^{-}\right)$group also appear as a triplet peak at $3.90 \mathrm{ppm}$. The methylene protons next to the heterocyclic ring sulfur atom ( $\mathrm{HetSC} \mathrm{H}_{2} \mathrm{CH}_{2}-$ ) have a chemical shift of $3.18 \mathrm{ppm}$ as a triplet peak. The methyl protons attached to the quaternary $\mathrm{N}$ atom $\left[\mathrm{N}^{+}\left(\mathrm{CH}_{3}\right)_{2}\right]$ have a chemical shift of $3.15 \mathrm{ppm}$ as a singlet peak, which are the essential characteristic peaks of this compound (Figure 1). The surfactant is not soluble in water at room temperature but is readily soluble by mild heating. Physicochemical parameters such as foam height and foam stability could not be determined because this compound did not form a permanent foam layer in water. However, various parameters like density $(\rho), \mathrm{cmc}$, surface tension at $\mathrm{cmc}\left(\gamma_{\mathrm{cmc}}\right)$, surface effectiveness $\left(\Pi_{\mathrm{cmc}}\right)$, Gibbs free energy of micellization $\left(\Delta G_{m i c}\right)$, and hydrophilic-lipophilic balance $(H L B)$ value were measured and/or calculated for the surfactant. The results are summarized in Table 1. 

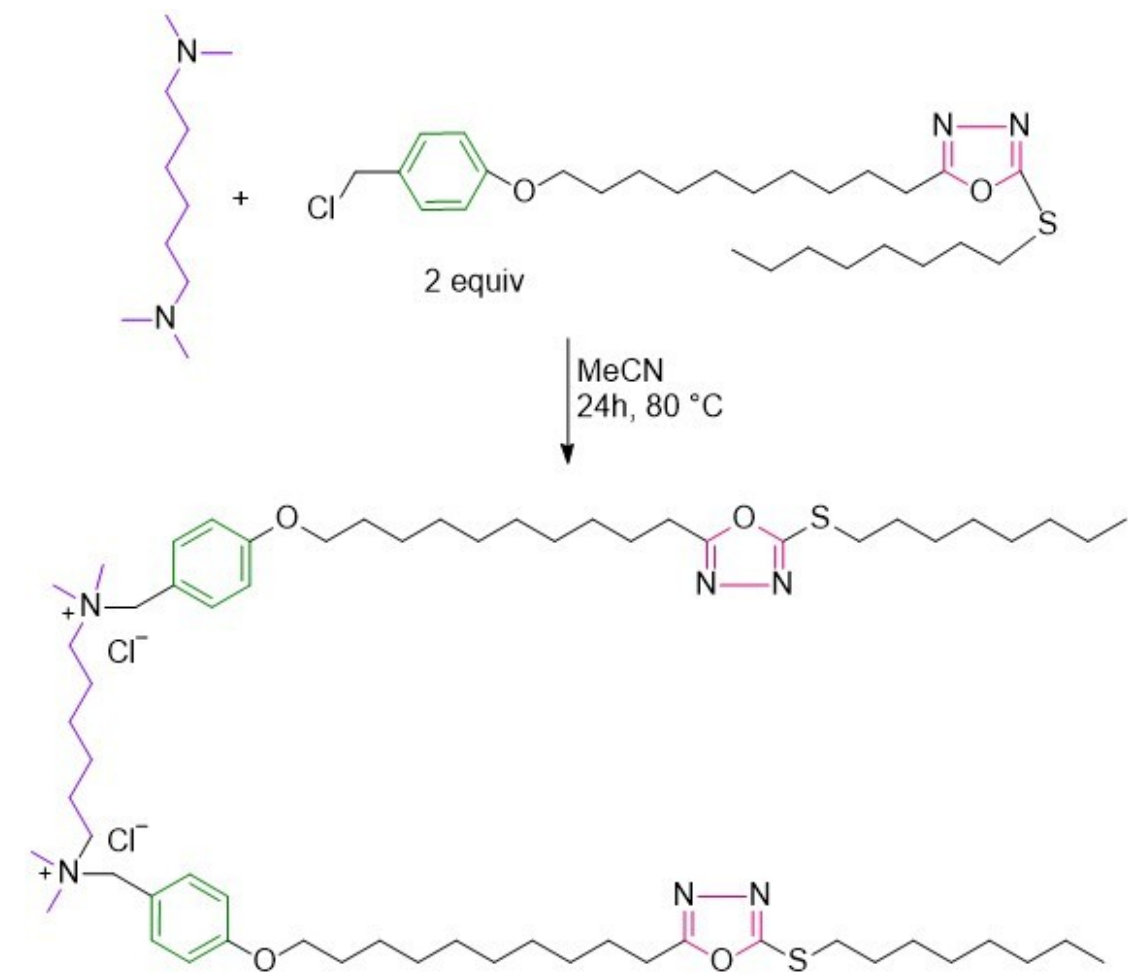

Scheme 1: Synthesis of symmetrical heterocyclic gemini-type surfactant.
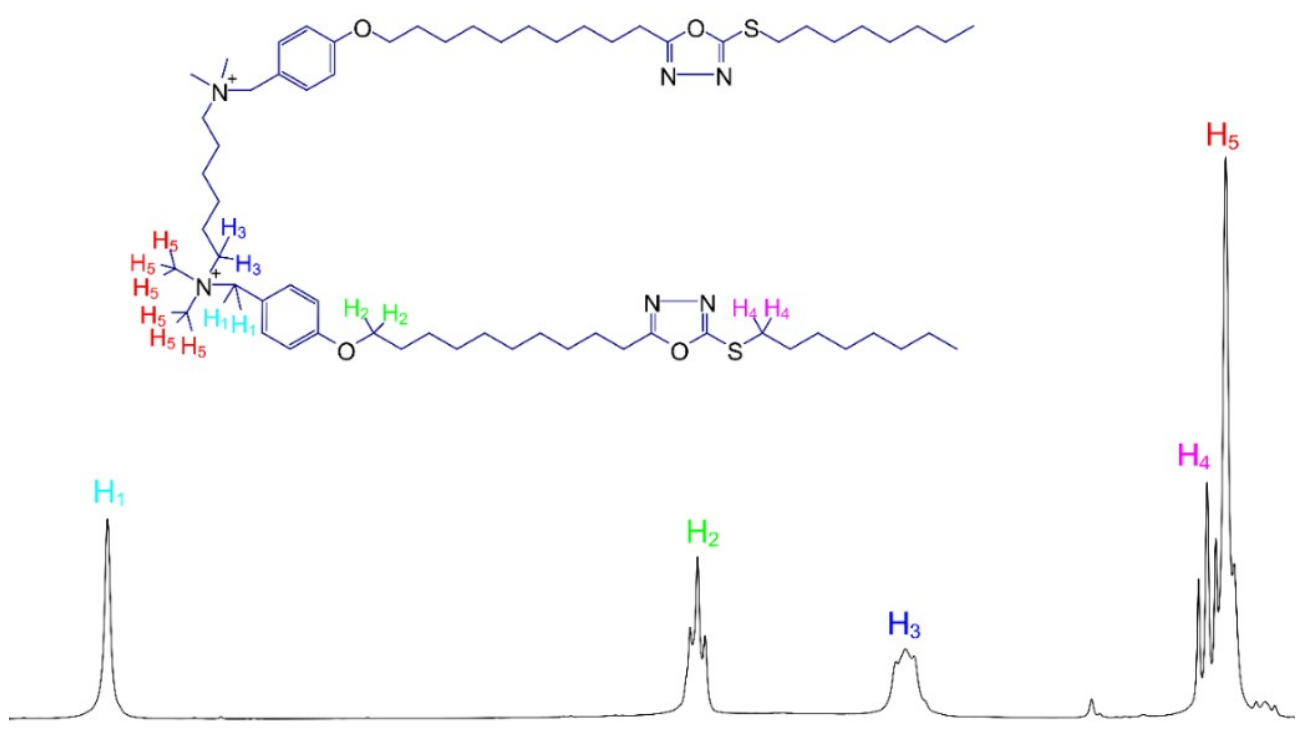

$\begin{array}{llllllllllllllllllll}4.8 & 4.7 & 4.6 & 4.5 & 4.4 & 4.3 & 4.2 & 4.1 & 4.0 & 3.9 & 3.8 & 3.7 & 3.6 & 3.5 & 3.4 & 3.3 & 3.2 & 3.1\end{array}$ f1 (ppm)

Figure 1: Some characteristic ${ }^{1} \mathrm{H}$ NMR peaks of the surfactant molecule. 
Table 1: Experimental and calculated physicochemical properties of the surfactant catalyst.

\begin{tabular}{|c|c|c|c|c|c|c|}
\hline $\begin{array}{c}\rho \\
\left(\mathrm{g} \mathrm{mL}^{-1}\right)^{\mathrm{a}, \mathrm{b}}\end{array}$ & $\begin{array}{c}c m c \\
\left(\times 10^{-5} \mathrm{mM}\right)^{\mathrm{a}}\end{array}$ & $\begin{array}{c}Y_{c m c} \\
\left(\text { dyn } \mathrm{cm}^{-1}\right)^{\mathrm{a}}\end{array}$ & $\begin{array}{c}\Pi_{c m c} \\
\left(\text { dyn } \mathrm{cm}^{-1}\right)\end{array}$ & $\begin{array}{c}\Delta G_{m i c} \\
\left(\mathrm{kj} \mathrm{mol}^{-1}\right)\end{array}$ & $\begin{array}{c}E S_{1} \\
(\mathrm{~s})^{\mathrm{a}, \mathrm{b}, \mathrm{d}}\end{array}$ & $\begin{array}{c}E S_{2} \\
(\mathrm{~s})^{\mathrm{a}, \mathrm{c}, \mathrm{d}}\end{array}$ \\
\hline 1.1227 & 26.36 & 33.01 & 39.79 & -36.9 & 164 & 38 \\
\hline
\end{tabular}

HLB (Hydrophilic-lipophilic balance) value of the surfactant molecule Hydrophilic and hydrophobic group contributions ${ }^{e}$

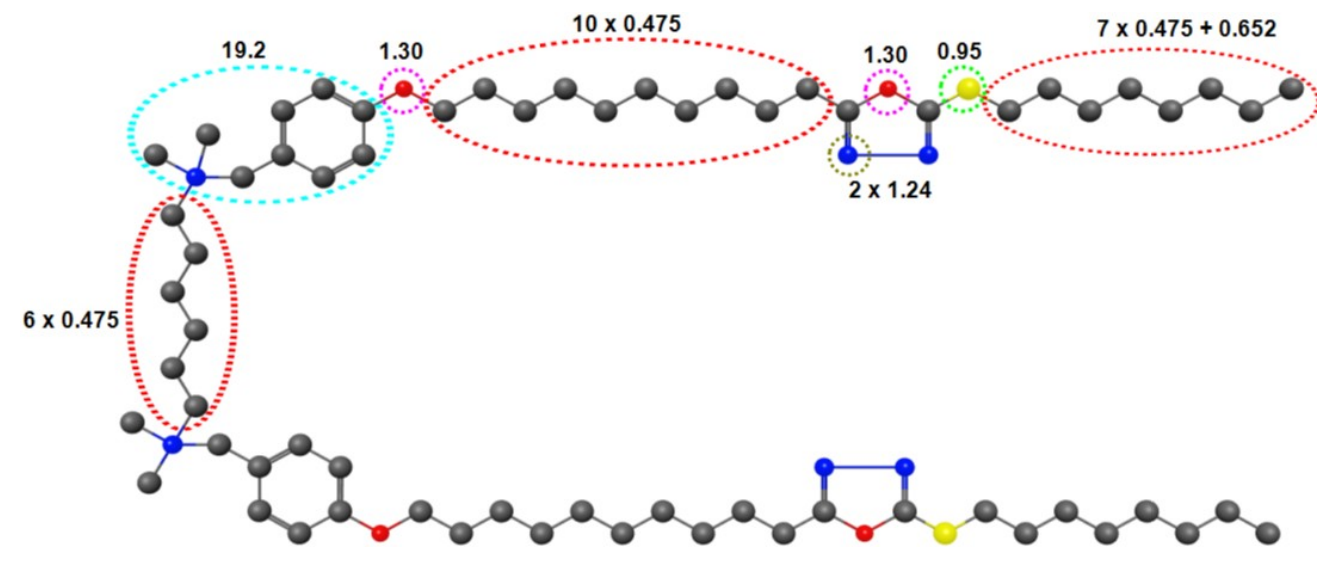

$H L B=\Sigma$ (Hydrophilic group contributions) $-\Sigma$ (Hydrophobic group contributions) +7

$=(19.2 \times 2+4 \times 1.30+4 \times 1.24+2 \times 0.95)-(40 \times 0.475+2 \times 0.652)$

$=30.2$

a value measured at $20^{\circ} \mathrm{C}$.

b Value measured at $1,0 \times 10^{-4} \mathrm{M}$ of surfactant concentration.

c Value measured at critical micelle concentration of the surfactant.

d Emulsion stability in seconds.

e Contributions were received from references $(35,36)$.

The cmc of the surfactant was determined by conductivity measurements. As seen in Figure 2, with the increase in conductivity, the concentrations also showed a linear increase. Besides, the concentration was determined as $26.36 \times 10^{-5} \mathrm{mM}$ at which the slope was changed. This concentration is the critical micelle concentration of the synthesized gemini surfactant and is relatively low in comparison with $\mathrm{cmc}$ values of previously synthesized cationic gemini surfactants (37). The surfactant's cmc plays an essential role in the Gibbs free energy of micellization. The value of Gibbs free energy of micellization, which is calculated by the following equation, proves that as the $\mathrm{cmc}$ of the surfactant decreases, the tendency of the substance to form micelle increases. The negative value of Gibbs' free energy of micellization shows that micelle formation occurs spontaneously.

$$
\Delta G_{m i c}=R T \times \ln (\mathrm{cmc})
$$

Where $\Delta G_{\text {mic }}$ is the Gibbs free energy of micellization, $\mathrm{R}$ is the ideal gas constant (8.314 J $\left.\mathrm{mol}^{-1} \mathrm{~K}^{-1}\right), \mathrm{T}$ is the absolute temperature (293 K). 


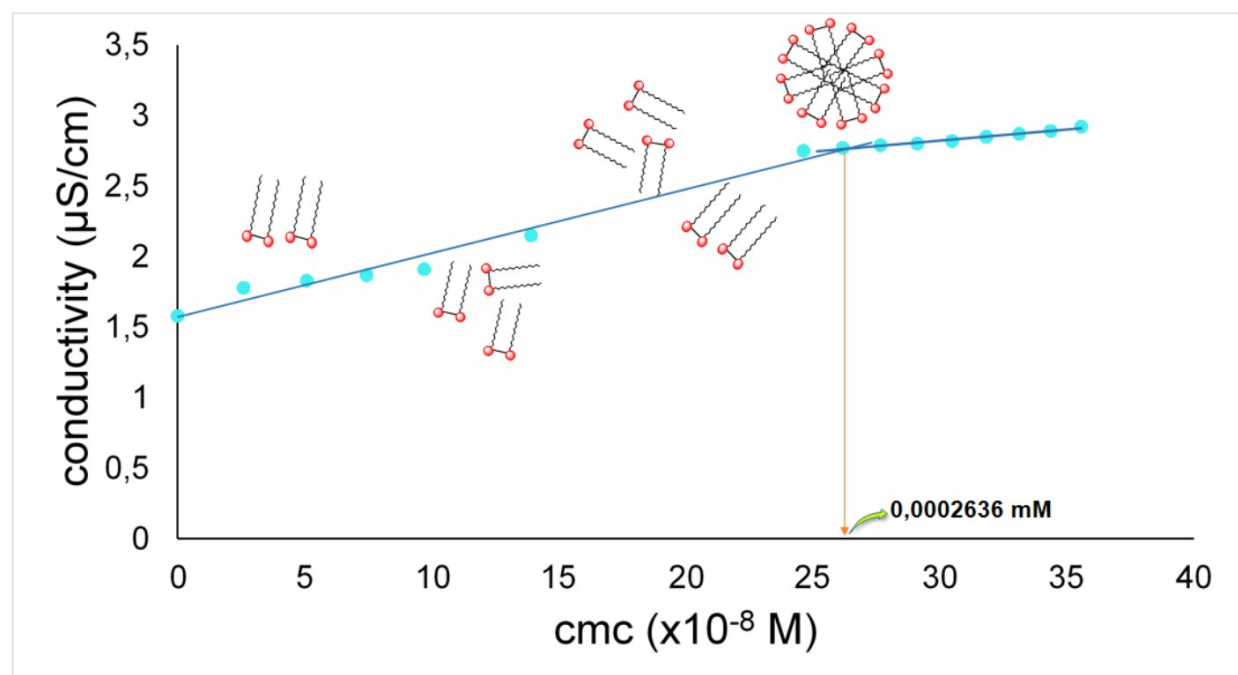

Figure 2. Conductivity as a function of surfactant concentration.

The surface tension was measured to evaluate the surface activity of the aqueous solution of the surfactant at cmc with a capillary rise method in accordance $(32,33)$. The effectiveness in surface tension reduction $\left(\Pi_{\mathrm{cmc}}\right)$ is the amount of reduction in surface pressure attained at the $\mathrm{cmc}(38)$. It is defined by using the following equation:

$$
\pi_{c m c}=\gamma_{0}-\gamma_{c m c}
$$

Where, $\gamma_{0}$ is the surface tension of pure solvent (water, $72.8 \mathrm{dyn} \mathrm{cm}^{-1}$ at $20{ }^{\circ} \mathrm{C}$ ) and $\gamma_{c m c}$ is the surface tension of the solution at the $\mathrm{cmc}$. This parameter $\left(\pi_{c m c}\right)$ indicates the maximum reduction of surface tension caused by the dissolution of surfactant molecules and hence becomes a measure for the effectiveness of the surfactant to lower the surface tension of the solvent (39). The effectiveness value was calculated as 39.79 dyn $\mathrm{cm}^{-1}$. This result indicates that the synthesized surfactant has the potential to reduce the surface tension in the aqueous system (40). The $H L B$ value is also calculated for the synthesized surfactant according to the Davies method (41).

One of the essential properties of surfactant molecules is emulsion stability, and it reflects the capability of a surfactant to maintain an emulsion for a longer duration. It was determined as a time required to break down the emulsion formed between surfactant solution and mineral oil. The emulsification is realized by the effect of adsorption, and it forms a layer of adsorptive film in the interface of dispersed droplets. The emulsion stability of the synthesized surfactant was measured as the time required for separation of 9 $\mathrm{mL}$ of pure water from the emulsion formed between surfactant solution at $\mathrm{cmc}$ and mineral oil $(10 / 10 \mathrm{~mL})$. As depicted in Table 1 , the emulsion stability was measured at two different concentrations of the synthesized surfactant. $\mathrm{ES}_{1}$ is the emulsion stability measured at $1.0 \times 10^{-4} \mathrm{M}$ of surfactant concentration, and $E S_{2}$ is the emulsion stability measured at cmc. Although the emulsion stability $\mathrm{ES}_{1}$ was found higher than $\mathrm{ES}_{2}$, the results in Table 1 showed that the synthesized compound has a low emulsification tendency, and therefore, it can be used safely in various applications.

The UV spectra of the surfactant measured for different concentrations of aqueous solutions are given in Figure 3a. The UV spectrum of the slightly more concentrated surfactant solution $\left(1,0 \times 10^{-4} \mathrm{M}\right)$ was also taken (Figure $3 \mathrm{~b}$ ). In these spectra, a maximum absorbance value was measured in the wavelength of $232 \mathrm{~nm}$, and two narrow bands were also detected in the wavelength range of 272-280 nm.

As known, dimeric (gemini) surfactants are compounds consisting of more than one hydrophilic head group and a hydrophobic tail group linked by a rigid or a flexible spacer at or near the head groups. The spacer group may also possess hydrophobic or hydrophilic groups, short or long alkyl groups, rigid or flexible groups (42). These surfactants appear to be superior to the corresponding conventional monomeric surfactants. They have much lower $\mathrm{cmc}$, are more efficient in lowering the surface tension of water, and have better wetting and lime-soap dispersing properties (43). Gemini surfactants have widespread use, some of which are using as a phase transfer catalyst and finding applications in adsorption (44), analytical separations (45), solubilization processes (46), nanotechnology (47) and oil recovery (48). They also find use in the dissolution of dyes and pigments in the spinning and weaving industry (49). 


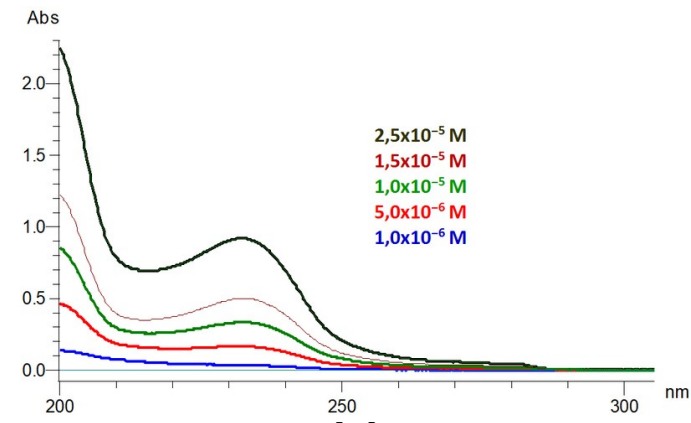

(a)

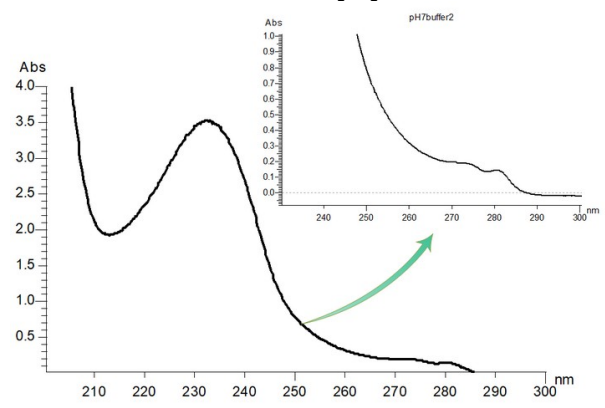

(b)

Figure 3. (a) UV spectra of aqueous solutions of the surfactant at different concentrations. Figure (b) UV spectrum of an aqueous solution of the surfactant at $1.0 \times 10^{-4} \mathrm{M}$.

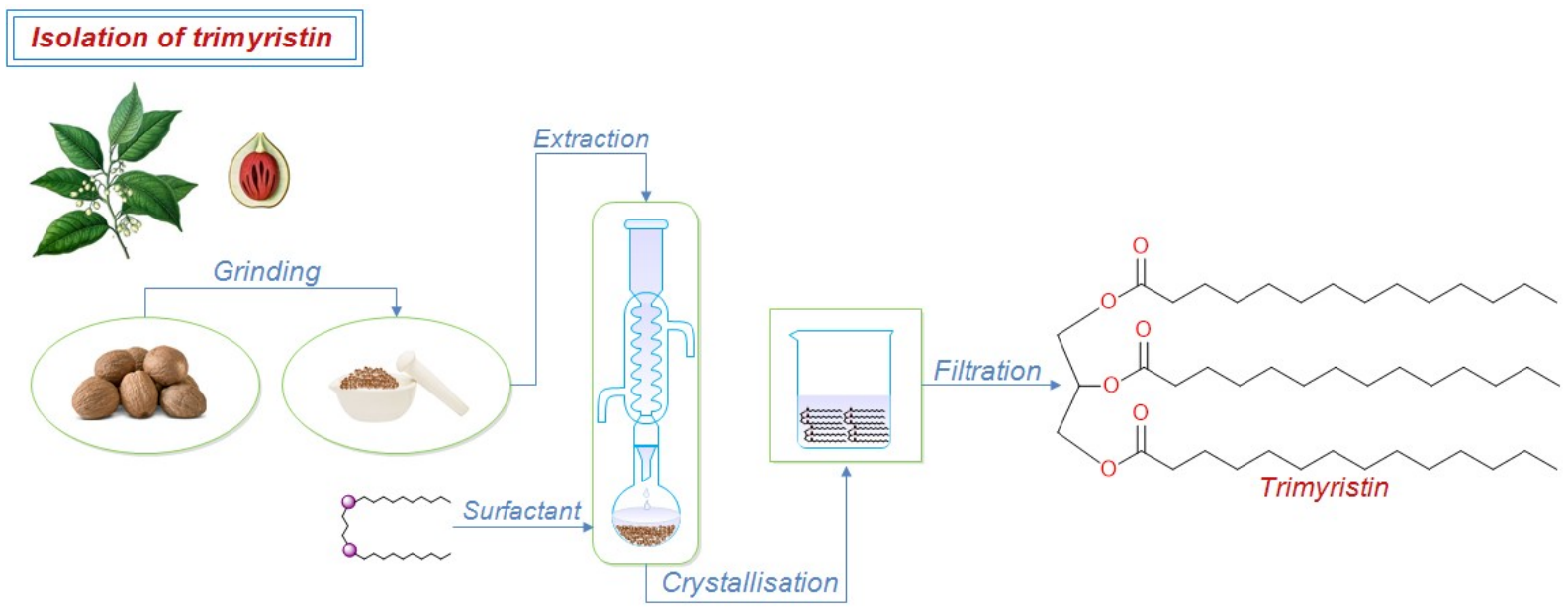

Scheme 2. Schematic representation of the trimyristin isolation process.

The possible role of the cationic surfactant during the extraction process can be expressed as in Figure 4. According to this figure, the surfactant molecules form a channel-like cavity for easier penetration of the non-polar solvent molecules from the semipermeable phospholipids based cell membrane. However, intriguing results were encountered in extractions with SDS as an anionic surfactant. As seen from Table 2, the amount of

\section{Extraction of trimyristin}

In this study, a series of extraction studies were carried out for the isolation of trimyristin from nutmeg (Scheme 2). The extractions were performed by slightly polar solvents $\left(\mathrm{CHCl}_{3}\right.$ and THF) and n-hexane as a non-polar solvent, all of which have a relatively low boiling point. Cationic and anionic monomeric surfactants such as cetyltrimethylammonium bromide (CTAB), cetylpyridinium bromide (CPB), and sodium dodecyl sulfate (SDS) respectively were selected, and their effectiveness was compared with the gemini surfactant (GS), to determine surfactant assistance in the isolation process (Table 2). It should be noted that the percent recovery yield of trimyristin is the yield after crystallization from acetone and is based on the recovered crude extract. As can be seen from the table, n-hexane, including gemini surfactant, is the more efficient system comparing to the other extracting neat solvents and surfactant-based solvent systems. The crude extract obtained at the end of the extraction with n-hexane is quite clear and colorless, so the purification of trimyristin becomes a simple task. On the other hand, orange-colored extracts obtained by extraction processes with the other slightly polar solvents, indicating that some moderately polar components of nutmeg essential oil are also transferred to the solvent phase along with trimyristin. 
Table 2. Experimental conditions for the extraction of trimyristin.

\begin{tabular}{|c|c|c|c|c|c|c|}
\hline Entry & Surfactant & Solvent & $\begin{array}{c}\text { Surfactant } \\
\text { (mg) }\end{array}$ & $\begin{array}{l}\text { Time } \\
(\min )\end{array}$ & $\begin{array}{c}\text { Temperature } \\
\left({ }^{\circ} \mathrm{C}\right)\end{array}$ & $\begin{array}{c}\text { Recovery yields } \\
\text { based on crude } \\
\text { extract }(\%)^{f}\end{array}$ \\
\hline 1 & - & $\mathrm{CHCl}_{3}$ & 5 & 20 & 50 & 60 \\
\hline 2 & - & THF & 5 & 20 & 50 & 62 \\
\hline 3 & - & n-hexane & 5 & 20 & 50 & 63 \\
\hline 4 & CTAB & $\mathrm{CHCl}_{3}$ & 5 & 20 & 50 & 64 \\
\hline 5 & CTAB & THF & 5 & 20 & 50 & 72 \\
\hline 6 & CTAB & n-hexane & 5 & 20 & 50 & 69 \\
\hline 7 & $\mathrm{CPB}$ & $\mathrm{CHCl}_{3}$ & 5 & 20 & 50 & 71 \\
\hline 8 & CPB & THF & 5 & 20 & 50 & 74 \\
\hline 9 & CPB & n-hexane & 5 & 20 & 50 & 67 \\
\hline 10 & SDS & $\mathrm{CHCl}_{3}$ & 5 & 20 & 50 & 42 \\
\hline 11 & SDS & THF & 5 & 20 & 50 & 69 \\
\hline 12 & SDS & n-hexane & 5 & 20 & 50 & 57 \\
\hline 13 & GS & $\mathrm{CHCl}_{3}$ & 5 & 20 & 50 & 67 \\
\hline 14 & GS & THF & 5 & 20 & 50 & 66 \\
\hline 15 & GS & n-hexane & 5 & 20 & 50 & 76 \\
\hline
\end{tabular}

${ }^{\mathrm{f}}$ After crystallization from acetone.

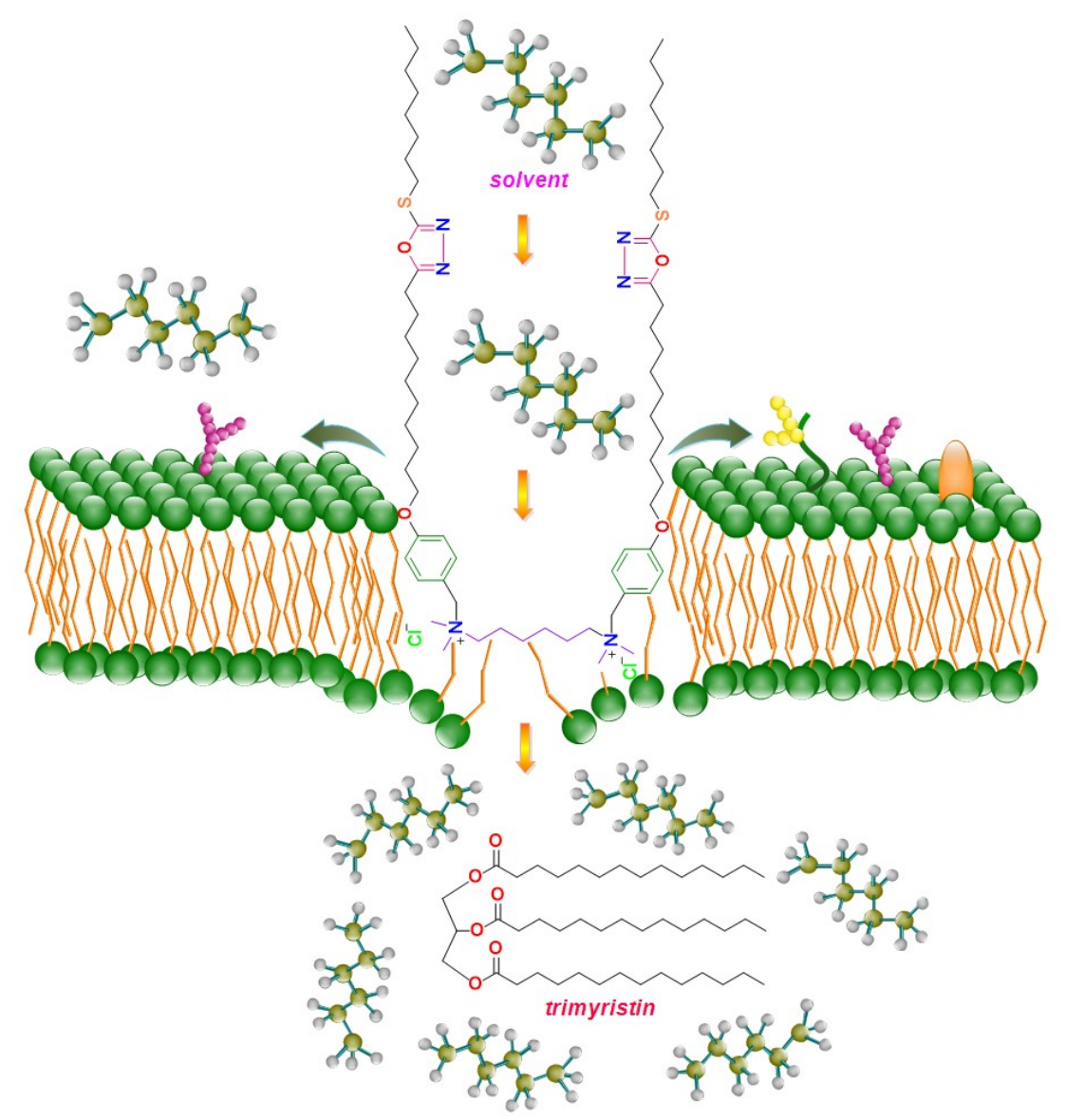

Figure 4. Plausible role of the surfactant molecule in the extraction process.

On the other hand, Table 2 shows that the ideal solvent and surfactant in the extraction process are n-hexane and GS, respectively. Accordingly, optimization studies were performed and the results obtained are shown in Figure 5 . When these results are evaluated, it can be concluded that the optimum conditions for the extraction of trimyristin with n-hexane should be as given in Figure 5, entry 5 . As a result, the most apparent advantages of the method developed in this study compared with the existing ones are that it allows obtaining triglyceride with more practical, selective, and high yields. 


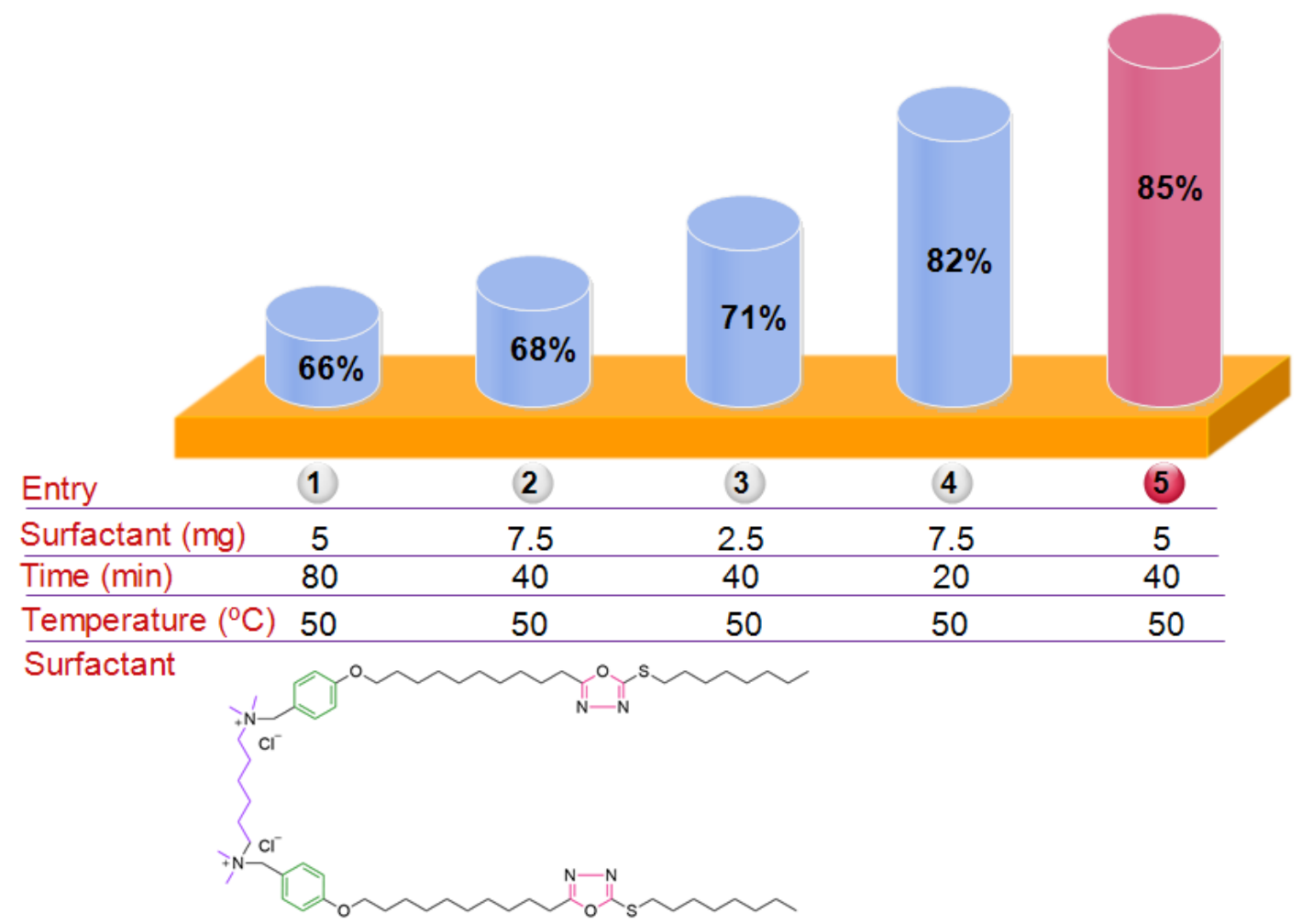

Figure 5. Optimization parameters for the recovery of trimyristin (percent yields are based on the crude extract after crystallization from acetone).

\section{CONCLUSIONS}

Herein, an extractive isolation method was developed for trimyristin from nutmeg as a valuable renewable raw material, and this method is more practical and effective than the existing isolation methods. Several different surfactants in combination with organic solvents, were used to make extraction more effective. It has been observed that monomeric and dimeric cationic surfactants, especially the newly synthesized gemini type surfactant, are more effective than the anionic surfactant (SDS) in the extraction process. The performed optimization studies revealed that to obtain the highest yield of the triglyceride, nhexane and gemini surfactant are ideal as an organic solvent and as an auxiliary agent, respectively.

\section{REFERENCES}

1. Metzger JO, Biermann U. Sustainable development and renewable feedstocks for chemical industry. In: Bozell $\mathrm{JJ}$ Patel MK, editors. Feedstocks for the Future, Renewables for the Production of Chemicals and Materials. Washington, DC: American Chemical Society; 2006 Jan, Vol. 921 , p. $13-26$.

2. Biermann $U$, Bornscheuer $U$, Meier MAR, Metzger JO, Schäfer $\mathrm{HJ}$. Oils and fats as renewable raw materials in chemistry. Angew. Chem. Int. Ed. 2011 Mar; 50:38543871.
3. Wiggers VR, Beims RF, Ender L, Simionatto EL, Meier $\mathrm{HF}$. Renewable hydrocarbons from triglyceride's thermal cracking frontiers in bioenergy and biofuels. In: Lopes EJ, Zepka LQ, editors. Frontiers in Bioenergy and Biofuels. London: IntechOpen Limited; 2017 Jan, p. 407-424.

4. Agyeman GA, Gyamerah M, Biney PO, Woldesenbet S. Extraction and characterization of triglycerides from coffeeweed and switchgrass seeds as potential feedstocks for biodiesel production. J. Sci. Food Agric. 2016 Mar; 96: 4390-4397.

5. Kubickova I, Kubicka D. Utilization of triglycerides and related feedstocks for production of clean hydrocarbon fuels and petrochemicals: a review. Waste Biomass Valori. 2010 Aug; 1: 293-308.

6. Lligadas G, Ronda JC, Galià M, Cádiz V. Oleic and undecylenic acids as renewable feedstocks in the synthesis of polyols and polyurethanes. Polymers 2010 Oct; 2: 440-453.

7. Maher KD, Bressler DC. Pyrolysis of triglyceride materials for the production of renewable fuels and chemicals. Bioresour. Technol. 2007 Sep; 98: 23512368.

8. Fréty $R$, Da Rocha MGC, Brandão ST, Pontes LAM, Padilha JF, Borges LEP, Gonzalez WA. Cracking and hydrocracking of triglycerides for renewable liquid fuels: alternative processes to transesterification. J. Braz. Chem. Soc. 2011 July; 22: 1206-1220.

9. Crivello JV, Narayan R. Epoxidized triglycerides as renewable monomers in photoinitiated cationic polymerization. Chem. Mater. 1992 May; 4: 692-699. 
10. Wells PA, Foster NR, Liong KK, Chaplin RP. Supercritical fluid extraction of triglycerides. Sep. Sci. Technol. 1990 Oct; 25: 139-154.

11. Temelli F. Extraction of triglycerides and phospholipids from canola with supercritical carbon dioxide and ethanol. J. Food Sci. 1992 March; 57: 440443.

12. Chen $\mathrm{WH}$, Chen $\mathrm{CH}$, Chang $\mathrm{CMJ}$, Chiu $\mathrm{YH}$, Hsiang $\mathrm{D}$. Supercritical carbon dioxide extraction of triglycerides from Jatropha curcas L. seeds. J. Supercrit. Fluids 2009 Dec; 51: 174-180.

13. Spricigo BC, Pinto LT, Bolzan A, Novais AF. Extraction of essential oil and lipids from nutmeg by liquid carbon dioxide. J. Supercrit. Fluids 1999 July; 15: 253-259.

14. Working paper, Food and Agriculture Organization of the United Nations, Rome, Nutmeg and derivatives, http://www.fao.org/3/v4084e/v4084e.pdf/, 1994 (accessed 10 June 2019).

15. Muchtaridi AS, Apriyantono A, Mustarichie R. Identification of compounds in the essential oil of nutmeg seeds (Myristica fragrans Houtt.) that inhibit locomotor activity in mice. Int. J. Mol. Sci. 2010 Nov; 1: 47714781.

16. Krishnamoorthy $B$, Rema J. Nutmeg and mace, in: Peter KV (Ed.), Handbook of Herbs and Spices, Woodhead Publishing, Cambridge, vol. 1, 2012, pp. 399416.

17. Beal GD. Trimyristin, Org. Synth. 1926; 6: 100.

18. Ikan R. Natural Products a Laboratory Guide, second ed., Academic Press, Inc., London, 1991, pp. 26-27.

19. Lugemwa FN. Extraction of betulin, trimyristin, eugenol and carnosic acid using water-organic solvent mixtures. Molecules 2012 Aug; 17: 9274-9282.

20. Frank F, Roberts T, Snell J, Yates C, Collins J. Trimyristin from nutmeg. J. Chem. Educ. 1971 Apr; 48: 255-256.

21. De Mattos MCS, Nicodem DE. Soap from nutmeg: an integrated introductory organic, chemistry laboratory experiment. J. Chem. Educ. 2002 Jan; 79: 94-95.

22. Leser $M E$, Luisi $P L$, Paimieri $S$. The use of reverse micelles for the simultaneous extraction of oil and proteins from vegetable meal. 1989 Nov; 34: 11401146.

23. Prevot $A B$, Gulmini $M$, Zelano $V$, Pramauro $E$. Microwave-assisted extraction of polycyclic aromatic hydrocarbons from marine sediments using Nonionic surfactant solutions. Anal. Chem. 2001 June; 73: 37903795.

24. Shi Z, Zhu X, Cheng Q, Zhang H. Micellar extraction and preconcentration of anthraquinone derivatives from rhubarb prior to their HPLC-DAD determination. J. Liq. Chromatogr. Relat. Technol. 2007 Feb; 30: 255-271.
25. Ugolini L, De Nicola G, Palmieri S. Use of reverse micelles for the simultaneous extraction of oil, proteins, and glucosinolates from cruciferous oilseeds. J. Agric. Food Chem. 2008 Feb; 56: 1595-1601.

26. Li F, Yu Y, Zhang $H$, Liu T, Lia Y, Duan G. Infraredassisted non-ionic surfactant extraction as a green analytical preparatory technique for the rapid extraction and pre-concentration of picroside I and picroside II from Picrorhiza scrophulariiflora Pennell. Anal. Methods 2013 May; 5: 3747-3753.

27. Tuntiwiwattanapun N, Tongcumpou C, Haagenson D, Wiesenborn D. Development and scale-up of aqueous surfactant-assisted extraction of canola oil for use as biodiesel feedstock. J. Am. Oil Chem. Soc. 2013 Apr; 90: 1089-1099.

28. Heng MY, Thio BJ, Ong ES. Surfactant-assisted pressurized liquid extraction at room temperature for radix glycyrrhizae by a new class of surfactants. J. Chromatogr. Sci. 2016 May-Jun; 54: 864-870.

29. Ramly NH, Zakaria R, Naim MN. Surfactant-assisted aqueous extraction of palm-pressed mesocarp fiber residual oil with Tween 80 solution. Sep. Sci. Technol. 2017 May; 52: 1796-1805.

30. Kadioglu SI, Phan TT, Sabatini DA. Surfactant-based oil extraction of corn germ. J. Am. Oil Chem. Soc. 2011 June; 88: 863-869.

31. Yıldırım A. Synthesis of novel alkyl-sulfanyl-1,3,4oxadiazolyl-1,3,5,7-tetraazatricyclic ammonium chloride type cationic surfactants. J. Het. Chem. 2015 March; 52: 522-526.

32. Martino W, De la Mora JF, Yoshida Y, Saito G, Wilkes J. Surface tension measurements of highly conducting ionic liquids. Green Chem. 2006 Jan; 8: 390-397.

33. Sugden $\mathrm{S}$. The determination of surface tension from the rise in capillary tubes. J. Chem. Soc., Trans. 1921; 119: 1483-1492.

34. Negm NA, Mohamed AS. Surface and thermodynamic properties of diquaternary bola-form amphiphiles containing an aromatic spacer. J. Surf. Deterg. 2004 Jan; 7: $23-30$

35. Akzo Nobel surface chemistry LLC, Technical information surface chemistry. HLB \& emulsification description of hydrophile, lipophile balance and use of HLB in producing emulsions. https://vdocuments.site/documents/akzonobel-tb-

hlbemulsions.html/, 2008 (accessed 10 June 2019).

36. Szymanowski J, Voelkel A. Hydrophile lipophile balance of hydroxyoximes in McGowan scale and their partition and extraction properties. J. Chem. Tech. Biotechnol. 1992 Oct; 54: 19-26.

37. Singh V, Tyagi R. Unique micellization and $\mathrm{cmc}$ aspects of gemini surfactant: an overview. J. Disper. Sci. Technol. 2014 Aug; 35: 1774-1792.

38. Öztürk S, Yıldırım A, Gece G, Türkdemir H. Flexible semicrown ether-linked symmetric cationic gemini surfactants: synthesis and evaluation as catalysts for 
acceleration of diastereoselective $[3+2]$ cycloaddition reaction in reversed phase micellar media. J. Surf. Deterg. 2019 Nov; 22: 197-208.

39. Dong $B$, Li N, Zheng L, Yu L, Inoue $T$. Surface adsorption and micelle formation of surface active ionic liquids in aqueous solution. Langmuir 2007 Mar; 23: 4178-4182.

40. El-Sayed R, Alotaibi HH, Elhady HA. Synthesis, surface parameters, and biodegradability of water-soluble surfactants for various applications. J. Oleo Sci. 2018 May; 67: 551-569.

41. Davies JT. A quantitative kinetic theory of emulsion type, I. physical chemistry of the emulsifying agent, in : Schulman JH. (Ed.), Proceedings of the second international congress of surface activity: Gas-liquid and liquid-liquid interface. Butterworths, London, 1957 pp. 426-438.

http://citeseerx.ist.psu.edu/viewdoc/download? $\mathrm{do}=10.1 .1 .473 .424 \&$ rep $=$ rep1\&type $=p d f /$, (accessed 10 June 2019).

42. Zana R, Xia J. Introduction, in: Zana R, Xia J. (Eds.), Gemini Surfactants: Synthesis, Interfacial and SolutionPhase Behavior, and Application. Marcel Dekker Inc., New York, 2004, pp. 1-8.

43. Tawfik SM. Synthesis, surface, biological activity and mixed micellar phase properties of some biodegradable gemini cationic surfactants containing oxycarbonyl groups in the lipophilic part. J. Ind. Eng. Chem. 2015 Aug; 28: 171-183.
44. Laschewsky A, Wattebled L, Arotçaréna M, Jiwan JLH, Rakotoaly RH. Synthesis and properties of cationic oligomeric surfactants. Langmuir, 2005 July; 21: 71707179.

45. Li W, Sun C, Hou B, Zhou X. Room temperature synthesis and catalytic properties of surfactant-modified Ag nanoparticles. Int. J. Spectrosc. 2012 July; 2012.

46. Han $Y$, Wang $Y$. Aggregation behavior of gemini surfactants and their interaction with macromolecules in aqueous solution. Phys. Chem. Chem. Phys. 2011 Jan; 13: $1939-1956$

47. Crescenzo AD, Germani R, Canto ED, Giordani S, Savelli G, Fontana A. Effect of surfactant structure on carbon nanotube sidewall adsorption. Eur. J. Org. Chem. 2011 Aug; 2011: 5641-5648.

48. Rosen $\mathrm{M}$, Wang $\mathrm{JH}$, Chen $\mathrm{P}$, Zhu $\mathrm{Y}$. Ultralow interfacial tension for enhanced oil recovery at very low surfactant concentrations. Langmuir 2005 Mar; 21: 3749-3756.

49. Idouhar M, Tazerouti A. Spectrophotometric determination of cationic surfactants using Patent Blue V: application to the wastewater industry in Algiers. J. Surfactants Deterg. 2008 Dec; 11: 263-267.

50. Pekker $M$, Shneider MN. Interaction between electrolyte ions and the surface of a cell lipid, membrane. J. Phys. Chem. Biophys. 2015 Mar; 5: 1000177. 
YILDIRIM A et al. JOTCSA. 2020; 7(2): 545-560. 


\section{An improved isolation of trimyristin from Myristica fragrans as a renewable feedstock with the assistance of novel cationic gemini surfactant}

Ayhan YILDIRIM, Serkan ÖZTÜRK, Haluk TÜRKDEMIR, Atakan KOLALI, Beyza Gökçem ATALAY, Hatice KOCATAŞ

Department of Chemistry, Faculty of Arts and Sciences, Bursa Uludağ University, Bursa 16059, Turkey

\section{Supplementary material}

Table of Contents:

FTIR spectrum for the gemini surfactant

$1 \mathrm{H}$ NMR spectrum for the gemini surfactant

13C NMR spectrum for the gemini surfactant

Figure S2

Figure S3 


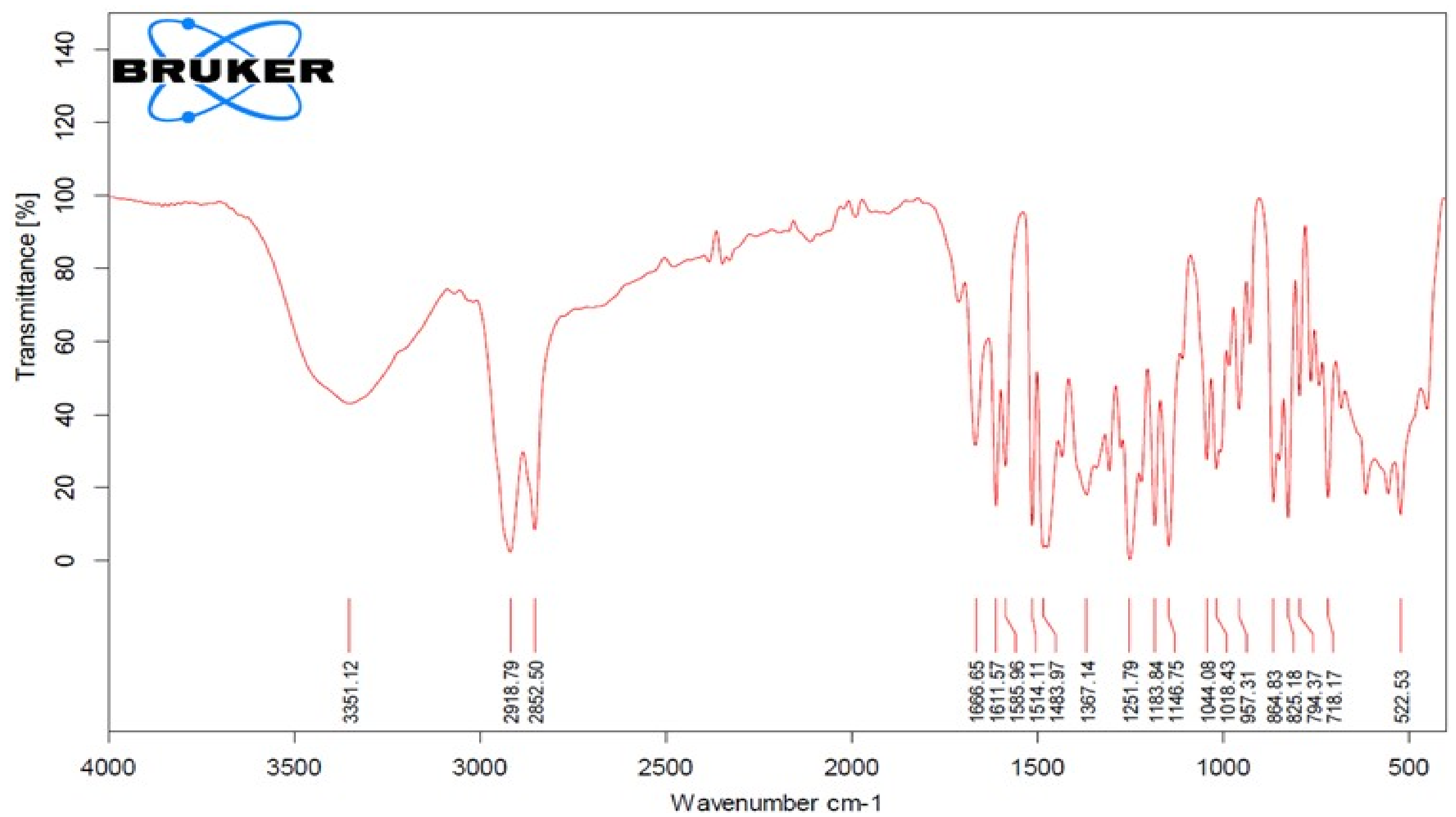

Figure S1. FTIR Spectrum. 


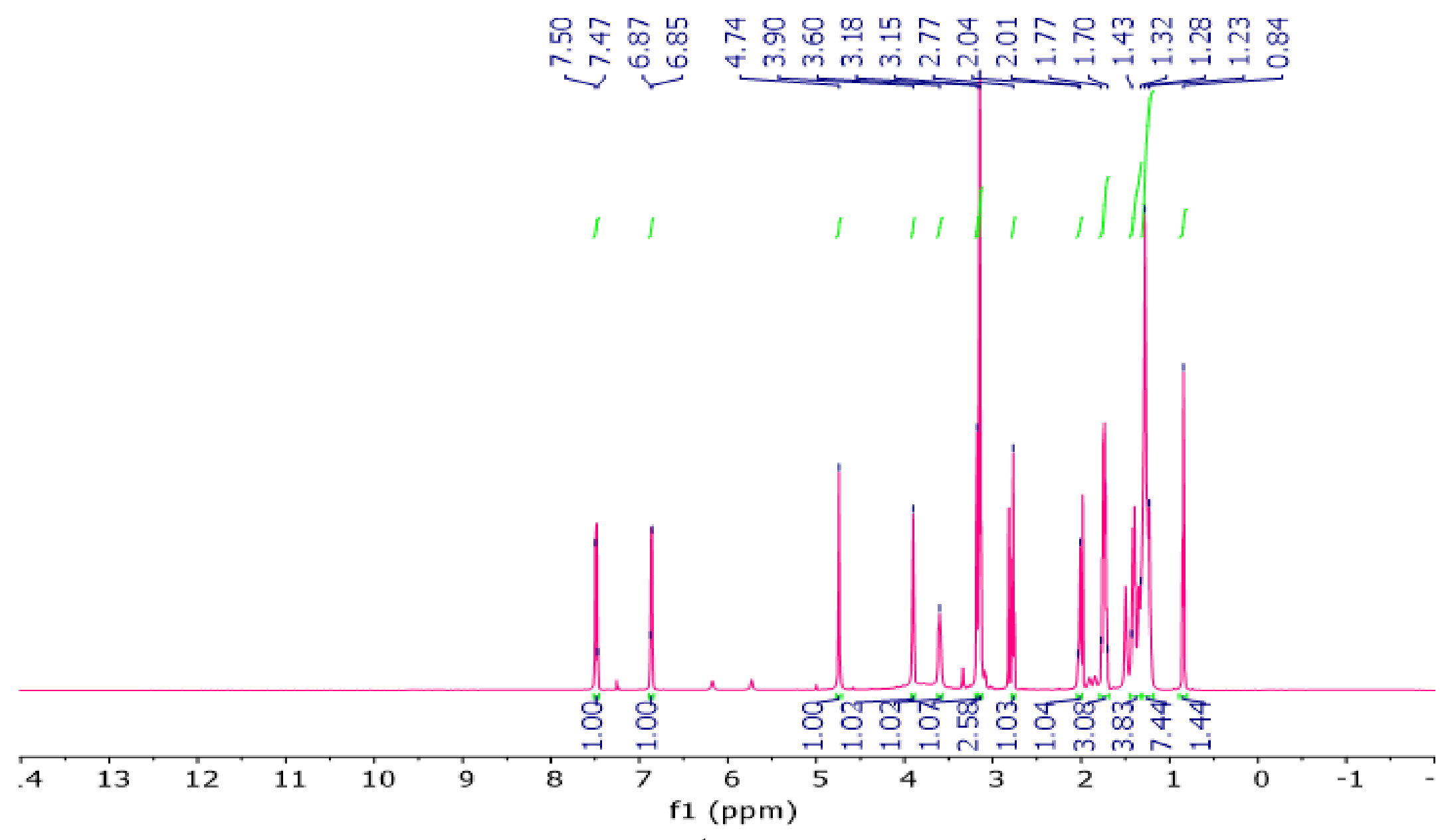

Figure S2. ${ }^{1 \mathrm{H}}$ NMR Spectrum. 


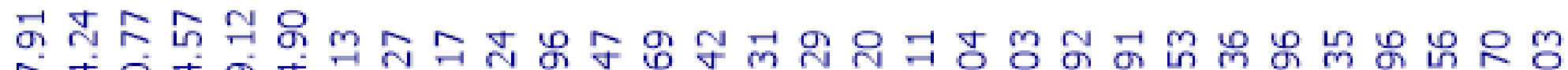

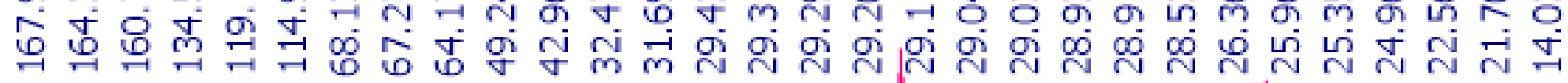

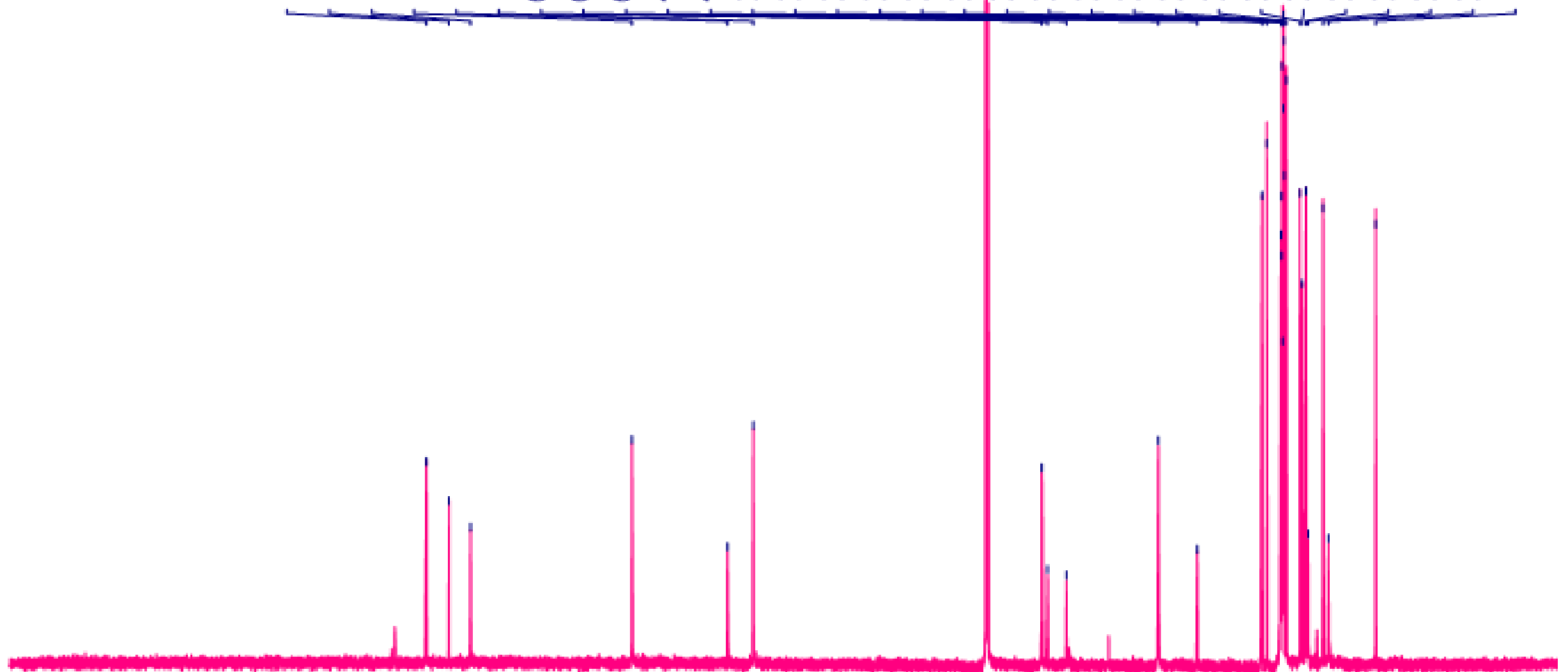

\begin{tabular}{|c|c|c|c|c|c|c|c|c|c|c|c|c|}
\hline 230 & 210 & 190 & 170 & 150 & 130 & $\begin{array}{l}110 \\
(p p\end{array}$ & 90 & 70 & 50 & 30 & 10 & -10 \\
\hline
\end{tabular}

Figure S3. ${ }^{13} \mathrm{C}$ NMR Spectrum. 